\title{
Dividend Dynamics in the Shipping Industry: A Panel Data Analysis of Partial Adjustment Models
}

\author{
Ioannis Chasiotis ${ }^{1}$, Dimitrios Konstantios' ${ }^{2}$, Vasilios-Christos Naoum ${ }^{2}$ \\ ${ }^{1}$ School of Business, Metropolitan College, Athens, Greece \\ ${ }^{2}$ Department of Maritime Studies, University of Piraeus, Piraeus, Greece \\ Email: ichasiotis@mitropolitiko.edu.gr, konstantios@unipi.gr, vcnaoum@unipi.gr
}

How to cite this paper: Chasiotis, I., Konstantios, D., \& Naoum, V.-C. (2021). Dividend Dynamics in the Shipping Industry: A Panel Data Analysis of Partial Adjustment Models. Theoretical Economics Letters, 11, 995-1001.

https://doi.org/10.4236/tel.2021.115063

Received: August 17, 2021

Accepted: October 25, 2021

Published: October 28, 2021

Copyright (C) 2021 by author(s) and Scientific Research Publishing Inc. This work is licensed under the Creative Commons Attribution International License (CC BY 4.0).

http://creativecommons.org/licenses/by/4.0/

\begin{abstract}
This study explores the dividend dynamics of globally-listed firms in the idiosyncratic maritime sector. Employing an array of dynamic panel estimators in a sample of globally-listed shipping firms for the period 1988 to 2019 we provide empirical evidence that the degree of dividend smoothing (speed of adjustment) in the maritime sector is comparatively lower (higher). We also show that the speed of adjustment after deviations from the target is significantly higher in recession states. Our results document higher flexibility in the shipping industry's dividend payouts, reflecting its distinct traits that amplify the adverse impacts of financing shocks.
\end{abstract}

\section{Keywords}

Dividend Smoothing, Speed of Adjustment, Maritime Industry, Recession, Shipping Companies

\section{Introduction}

The theoretical and empirical analysis of the dividend decision constitutes a focal point in corporate finance research. Lintner's (1956) seminal study evidences the tendency of firms to exercise a stable dividend policy, where current dividends are set according to their former levels. Moreover, firms appear to have a long-term target payout to which they adjust slowly after unexpected increases in earnings. This behavior, known as dividend smoothing is one of the most pronounced and well-documented phenomena in corporate finance research (Leary \& Michaely, 2011). Relevant ${ }^{1}$ empirical studies utilize national and inter-

${ }^{1}$ See the meta-analysis by Fernau \& Hirsch (2019). 
national, across-industry samples. The current study rides this wave of research and focuses on the global maritime industry. It tries to fill the relevant gap in the literature motivated by the importance and distinct traits of this sector. Commercial ships facilitate $90 \%$ of global trade while the maritime sector is characterized by high leverage, cyclicality, assets risk and financial constraints (Grammenos et al., 2008; Drobetz et al., 2013; Maniati \& Sambracos, 2017). The maritime sector's high-risk profile has shaped certain aspects of firm's financial decision-making such as a conservative cash-holding policy (Ahrends et al., 2018) and a higher capital structure speed of adjustment (Drobetz et al., 2013). However, dividend dynamics in this sector have not been investigated (Alexandridis et al., 2018). Moreover, considering that payout decisions relate to liquidity and internal financing capabilities (Iyer et al., 2017) it is of particular significance to improve our understanding of dividend behavior in this sector.

Therefore, in this study, we analyze the dividend dynamics of 147 globally-listed maritime companies to explore the presence and the degree of dividend smoothing. By estimating Lintner's (1956) model we document that shipping companies' smooth dividends. However, the degree of dividend smoothing (speed of adjustment) in the maritime sector is lower (higher) than the one estimated for the "average" industrial firm in earlier studies (see Fernau \& Hirsch, 2019). Moreover, we document that recessions in the macroeconomic and shipping environment exert a positive impact on the speed of adjustment. Our results indicate that the maritime sector exhibits a comparatively higher flexibility in dividends which is further amplified in recession states. This dividend behavior is in line with the sector's high-risk distinct traits. It appears that as earnings and external financing capabilities decline during recessions, maritime companies lower the degree of dividend smoothing to become more flexible. Thereby, increasing their ability to secure sufficient liquidity and investment capital. This study adds to the strand of the literature that documents the impact of the maritime industry's particularities in financial decision-making. Financial analysts have a keen interest in evaluating a firm's ability to avoid (i.e., financial flexibility) when deriving a firm's intrinsic value. Given that payout flexibility can have a direct impact on investment efficiency and financial distress, our findings provide useful insights to researchers, financial analysts and market participants in this sector.

\section{Methodology}

Lintner's (1956) seminal study documents several empirical observations regarding dividend decisions. Dividend stability represents a major managerial concern due to the belief that the market places a premium on stable dividend policies. Instead of deciding dividends de novo each year, firms appear to have a long-term dividend payout target. If there is an unexpected increase in earnings firms will only adjust their dividends slowly. Finally, managers are reluctant to cut dividends. 
To explore the dividend dynamics of maritime companies we employ Lintner's (1956) empirically testable partial adjustment model. In any given year, the target dividend payout $D_{i t}^{*}$ is determined by a desired dividend payout ratio $r_{i}$ of current earnings $E_{\text {t.t. }}$

$$
D_{i t}^{*}=r_{i} E_{i, t}
$$

However, each year a firm will only adjust partially to the target dividend payout.

$$
\Delta D_{i t}=D_{i t}-D_{i t-1}=a_{t}+\lambda_{i}\left(D_{i t}^{*}-D_{i t-1}\right)+\varepsilon_{t, t}
$$

where $\alpha_{i}$ is a constant, $\lambda_{i}$ is the speed-of-adjustment coefficient, $\Delta D_{i t}$ is the actual change in dividends, $D_{i t}^{*}-D_{i t-1}$ is the desired change in dividends and $\varepsilon_{t, t}$ is the error term.

A speed of adjustment coefficient $\left(\hat{\lambda}_{i}\right)$ with values between 0 and 1 suggests dividend smoothing, that is, firms partially adjust their dividend payout towards the target in a given period. If $\hat{\lambda}_{i}$ is estimated $0(1)$ then this implies a zero (perfect) adjustment. Equation (3) stems after rearranging Equation (2):

$$
D_{i t}=a_{t}+\lambda_{i} D_{i t}^{*}+\left(1-\lambda_{i}\right) D_{i t-1}+\varepsilon_{l, t}
$$

Equation (4) is derived by substituting Equation (1) to Equation (3)

$$
D_{i t}=a_{\imath}+\beta_{1 i} E_{i t}+\beta_{2 i} D_{i t-1}+\varepsilon_{l, t}
$$

where $\beta_{i}=\lambda_{i} r_{i}$ and $\beta_{2 i}=1-\hat{\lambda}_{i}$ represents the degree of dividend smoothing. We estimate Equation (3) with three different estimation techniques. We utilize a left-censored Tobit regression to adjust for the fact that we have censored observations, since dividends have a lower bound at zero. We also use a firm fixed-effects estimator to account for time invariant firm characteristics. Finally, we employ a GMM-in-differences estimator as it yields unbiased coefficient estimates of the lagged variable $\hat{\beta}_{2}$ (Baltagi, 2008).

Considering the distinct traits of the maritime sector we expect that maritime companies will exhibit a lower degree of dividend smoothing $\left(1-\hat{\lambda}_{i}\right)$ and a higher speed of adjustment $\left(\hat{\lambda}_{i}\right)$. The maritime sector is highly levered and cyclical, which hampers the financial flexibility of shipping firms. Specifically, uncertain and fluctuating profits as well a significant part of cash flows committed to interest payments lower the internal financing capabilities of the shipping industry and increase external financing costs. However, financial flexibility and the need to preserve it is identified as one the most important factors in shaping financial decision making (see surveys by Graham \& Harvey, 2001; Bancel \& Mittoo, 2004; Brav et al., 2005; Brounen et al., 2006). In this respect Ahrends et al. (2018) find that maritime companies practice a more conservative cash-holding policy, indicating an effort to maintain financial flexibility. Thus, we expect that maritime companies will exhibit a lower degree of dividend smoothing, where dividend changes trace more closely changes in profitability. Consider the cyclical nature of the maritime sector this will lead to more volatile dividend pay- 
ments and a higher speed of adjustment. Moreover, we expect that the need for flexibility in dividends will increases in recession states where the supply of credit diminishes, collateral values decline and costs of financial distress increase, thus deteriorating financing capabilities further. Accordingly, Drobetz et al. (2013) find that the capital structure speed of adjustment of maritime companies increases during recessions arguing that highly-levered shipping companies are pressured by their banks to swiftly readjust to the target.

\section{Data}

Our sample consists of global maritime companies and the firm-level data are retrieved from the Compustat Global database. Compustat global is a world-leading database of financial, statistical and market information and is provided by Standard and Poors. Following the literature, we exclude the following companies 1) shipyards and shipping 2) involved passenger shipping, 3) operate drilling ships 4) supply vessels, and 5) inland vessels. Our final sample includes 2158 firm-year observations from 147 maritime companies for the time period from 1988 to 2019. Table 1 provides the number of maritime firms including firm-year observations per country of incorporation. In total, the 147 maritime companies in our sample represent 33 countries. However, $40 \%$ of our firm-year observations and $45 \%$ of total firms come from 6 Asian countries and regions (Malaysia, Singapore, China, Hong-Kong (China), Thailand and Chinese Taipei) and one European (Norway).

Table 1. Maritime companies and firm years observations by country.

\begin{tabular}{|c|c|c|c|c|c|c|c|c|c|}
\hline \multicolumn{2}{|c|}{ Country/Region firm-years } & \multirow{2}{*}{$\begin{array}{c}\% \\
0.5 \%\end{array}$} & \multirow{2}{*}{$\begin{array}{c}\text { firms } \\
1\end{array}$} & \multirow{2}{*}{$\begin{array}{c}\% \\
0.68 \%\end{array}$} & \multirow{2}{*}{$\begin{array}{c}\text { Country/Region } \\
\text { KOR }\end{array}$} & \multirow{2}{*}{$\begin{array}{c}\text { firm-years } \\
44\end{array}$} & \multirow{2}{*}{$\begin{array}{c}\% \\
2.04 \%\end{array}$} & \multirow{2}{*}{$\begin{array}{c}\text { firms } \\
3\end{array}$} & \multirow{2}{*}{$\begin{array}{c}\% \\
2.03 \%\end{array}$} \\
\hline AUS & 11 & & & & & & & & \\
\hline BEL & 46 & $2.1 \%$ & 3 & $2.03 \%$ & LKA & 14 & $0.65 \%$ & 1 & $0.68 \%$ \\
\hline BGD & 11 & $0.5 \%$ & 1 & $0.68 \%$ & LTU & 20 & $0.93 \%$ & 2 & $1.35 \%$ \\
\hline BMU & 48 & $2.2 \%$ & 5 & $3.38 \%$ & LUX & 15 & $0.70 \%$ & 1 & $0.68 \%$ \\
\hline BRA & 25 & $1.2 \%$ & 1 & $0.68 \%$ & MCO & 3 & $0.14 \%$ & 2 & $1.35 \%$ \\
\hline CHL & 69 & $3.2 \%$ & 3 & $2.03 \%$ & MHL & 2 & $0.09 \%$ & 1 & $0.68 \%$ \\
\hline $\mathrm{CHN}$ & 110 & $5.1 \%$ & 5 & $3.38 \%$ & MYS & 176 & $8.16 \%$ & 9 & $6.08 \%$ \\
\hline DEU & 33 & $1.5 \%$ & 3 & $2.03 \%$ & NLD & 15 & $0.70 \%$ & 1 & $0.68 \%$ \\
\hline DNK & 87 & $4.0 \%$ & 5 & $3.38 \%$ & NOR & 237 & $10.98 \%$ & 25 & $16.89 \%$ \\
\hline FIN & 31 & $1.4 \%$ & 1 & $0.68 \%$ & SGP & 87 & $4.03 \%$ & 8 & $5.41 \%$ \\
\hline FRA & 5 & $0.2 \%$ & 4 & $2.70 \%$ & SWE & 75 & $3.48 \%$ & 10 & $6.76 \%$ \\
\hline GBR & 74 & $3.4 \%$ & 5 & $3.38 \%$ & THA & 115 & $5.33 \%$ & 7 & $4.73 \%$ \\
\hline GRC & 4 & $0.2 \%$ & 1 & $0.68 \%$ & Chinese Taipei & 120 & $5.56 \%$ & 6 & $4.05 \%$ \\
\hline HKG (China) & 110 & $5.1 \%$ & 5 & $3.38 \%$ & USA & 23 & $1.07 \%$ & 3 & $2.03 \%$ \\
\hline HRV & 7 & $0.3 \%$ & 1 & $0.68 \%$ & VNM & 9 & $0.42 \%$ & 1 & $0.68 \%$ \\
\hline IDN & 68 & $3.2 \%$ & 5 & $3.38 \%$ & $\mathrm{ZAF}$ & 6 & $0.28 \%$ & 1 & $0.68 \%$ \\
\hline IND & 99 & $4.6 \%$ & 3 & $2.03 \%$ & & & & & \\
\hline Total & & & & & & 2158 & $100 \%$ & 147 & $100 \%$ \\
\hline
\end{tabular}




\section{Results}

Table 2 shows the results from estimating Linter's (1965) partial adjustment model for our sample. Results indicate that maritime companies smooth dividends with a degree of dividend smoothing $\left(\beta_{2 i}=1-\hat{\lambda}_{i}\right)$ ranging from 0.56 (diff GMM-Panel B) to 0.83 (left-censored Tobit-Panel B) across different estimators. Table 3 reports the corresponding speed of adjustment-SOA $\left(\hat{\lambda}_{i}\right)$ as a percentage. Results show that $\hat{\lambda}_{i}$ ranges from $17 \%$ (left-censored Tobit-Panel B)

Table 2. Partial adjustment regressions.

\begin{tabular}{|c|c|c|c|}
\hline Panel A & Left-censored Tobit & $\mathrm{FE}$ & Diff-GMM \\
\hline \multirow[t]{2}{*}{ EPS } & $0.041^{* * *}$ & $0.002^{\star * *}$ & $0.003^{* * *}$ \\
\hline & $(0.003)$ & $(0.000)$ & $(0.001)$ \\
\hline \multirow[t]{2}{*}{$\mathrm{DPS}_{\mathrm{t}-1}$} & $0.798^{\star * *}$ & $0.682^{\star * \star}$ & $0.567^{\star * *}$ \\
\hline & $(0.010)$ & $(0.078)$ & $(0.059)$ \\
\hline \multirow[t]{2}{*}{ Macroeconomic Recessions } & 10.255 & 1.218 & 44.381 \\
\hline & $(6.544)$ & $(1.136)$ & $(27.160)$ \\
\hline \multirow{2}{*}{$\mathrm{DPS}_{\mathrm{t}-1}{ }^{*}$ Macroeconomic Recessions } & $-0.673^{\star *}$ & $-0.421^{\star \star}$ & $-0.492^{\star * *}$ \\
\hline & $(0.342)$ & $(0.189)$ & $(0.155)$ \\
\hline \multirow[t]{2}{*}{ Constant } & $-67.265^{\star *}$ & $5.897^{\star * *}$ & 1.493 \\
\hline & $(27.253)$ & $(0.665)$ & $(2.588)$ \\
\hline Observations & 2158 & 2158 & 2158 \\
\hline Panel B & Left-censored Tobit & $\mathrm{FE}$ & Diff-GMM \\
\hline \multirow[t]{2}{*}{ EPS } & $0.023^{* * *}$ & $0.001^{\star * \star}$ & $0.002^{\star *}$ \\
\hline & $(0.001)$ & $(0.000)$ & $(0.001)$ \\
\hline \multirow[t]{2}{*}{$\mathrm{DPS}_{\mathrm{t}-1}$} & $0.830^{* * *}$ & $0.711^{\star * *}$ & $0.560^{\star *}$ \\
\hline & $(0.254)$ & $(0.188)$ & $(0.258)$ \\
\hline \multirow[t]{2}{*}{ Shipping Recessions } & -11.308 & -2.213 & -29.080 \\
\hline & $(7.037)$ & $(3.064)$ & $(68.147)$ \\
\hline \multirow[t]{2}{*}{$\mathrm{DPS}_{\mathrm{t}-1} *$ Shipping Recessions } & -0.318 & $-0.445^{* * *}$ & $-0.402^{\star *}$ \\
\hline & $(0.266)$ & $(0.109)$ & $(0.165)$ \\
\hline \multirow[t]{2}{*}{ Constant } & $-66.794^{* * *}$ & $7.431^{* *}$ & 20.509 \\
\hline & $(23.611)$ & (3.543) & $(29.284)$ \\
\hline Observations & 2158 & 2158 & $0.002^{* *}$ \\
\hline
\end{tabular}

The dependent variable is dividend per share (DPS). Robust Standard errors are reported in parentheses. ${ }^{* * *} p<0.01,{ }^{* *} p<0.05,{ }^{*} p<0.1$.

Table 3. Speed of adjustment results (SOA), $\hat{\lambda}_{i}=1-\hat{\beta}_{2 i}$.

\begin{tabular}{cccc}
\hline Panel A & Left-censored Tobit & FE & Diff-GMM \\
\hline SOA & $20.2 \%$ & $31.8 \%$ & $46.7 \%$ \\
SOA-Macroeconomic Recessions & $28.7 \%$ & $37.2 \%$ & $49.6 \%$ \\
\hline Panel B & Left-censored Tobit & FE & Diff-GMM \\
\hline SOA & $17 \%$ & $28.9 \%$ & $44.0 \%$ \\
SOA-Shipping Recessions & $29.8 \%$ & $46.8 \%$ & $60.3 \%$ \\
\hline
\end{tabular}


to $46.7 \%$ (diff GMM-Panel A). This relatively wide range is generally documented in SOA estimations in national and international sample and can be at least to some extent attributed to biased coefficient estimated from applying different methods (Fernau \& Hirsch, 2019). Taking into consideration that the GMM-in-differences estimators yields unbiased coefficient (Baltagi, 2008) it appears that maritime companies exhibit a relatively low (high) degree of dividend smoothing $(\mathrm{SOA})^{2}$. A higher SOA indicates more volatility in dividend payouts of shipping firms suggesting that dividends in the maritime sector exhibit a higher level of flexibility. Specifically, dividend changes track more closely changes in profitability. This appears in line with the industry's particular need for flexibility stemming from its distinct characteristic such as high leverage, cyclicality, high asset risk and financial constraints. In further support of this contention the SOA increases in recession states. In both macroeconomic and shipping recessions the SOA appears elevated across all methods, with the estimated increase ranging from $3 \%$ to $18 \%$. Similar results regarding the impact of recessions on the SOA are reported by Rhee \& Park (2018) for a panel of Korean firms. It seems that as profitability and external financing opportunities deteriorate during recession states maritime companies adjust dividends more flexibly to secure sufficient liquidity and secure investment capital.

\section{Conclusion}

The current study investigates the dividend dynamics of globally-listed maritime companies. Our findings show that maritime companies exhibit a lower degree of dividend smoothing and a higher SOA than the "average" firm. Moreover, according to our evidence SOA increases in recession states both in the macroeconomic and the shipping environment. The increased dividend flexibility of maritime companies appears to be in line to the sector's high-risk profile. It seems that as profitability and external financing opportunities deteriorate during recession states maritime companies adjust dividends more flexibly to secure sufficient liquidity and investment capital. Our findings provide further insight in the shipping industry's distinctive financial decision-making. Therefore, considering fundamental sectoral differences, across-industry samples which report a single coefficient may not be as informative since they mask heterogeneous behavior. Finally, our findings confirm the impact of the macroeconomic environment on maritime firms' payout policy. Our results suggest that shipping companies follow a "flexible" payout policy. However, we do not explicitly control for other sources of financial flexibility such increased cash holdings, unused debt capacity or the use of freight derivatives. The interdependence or substitution between these financial decisions is as an interest avenue for future research which may shed further insight into the decision-making of maritime companies.

${ }^{2}$ The meta-analysis of dividend smoothing-studies using across-industry samples by Fernau \& Hirsch (2019) reports a "true" smoothing coefficient of 0.728 and thus a $27.2 \%$ speed of adjustment. 


\section{Conflicts of Interest}

The authors declare no conflicts of interest regarding the publication of this paper.

\section{References}

Ahrends, M., Drobetz, W., \& Nomikos, N. K. (2018). Corporate Cash Holdings in the Shipping Industry. Transportation Research Part E: Logistics and Transportation Review, 112, 107-124. https://doi.org/10.1016/j.tre.2017.10.016

Alexandridis, G., Kavussanos, M., Kim, C., Tsouknidis, D. A., \& Visvikis, I. (2018). A Survey of Shipping Finance Research: Setting the Future Research Agenda. Transportation Research Part E: Logistics and Transportation Review, 115, 164-212. https://doi.org/10.1016/j.tre.2018.04.001

Baltagi, B. H. (2008). Econometric Analysis of Panel Data. John Wiley \& Sons.

Bancel, F., \& Mittoo, U. R. (2004). Cross-Country Determinants of Capital Structure Choice: A Survey of European Firms. Financial Management, 33, 103-132.

Brav, A., Graham, J. R., Harvey, C. R., \& Michaely, R. (2005). Payout Policy in the 21st Century. Journal of Financial Economics, 77, 483-527. https://doi.org/10.1016/j.jfineco.2004.07.004

Brounen, D., Abe de Jong, A., \& Koedijk, K. (2006). Capital Structure Policies in Europe: Survey Evidence. Journal of Banking \& Finance, 30, 1409-1442. https://doi.org/10.1016/j.jbankfin.2005.02.010

Drobetz, W., Gounopoulos, D., Merikas, A. G., \& Schröder, H. (2013). Capital Structure Decisions of Globally-Listed Shipping Companies. Transportation Research Part E: Logistics and Transportation Review, 52, 49-76. https://doi.org/10.1016/j.tre.2012.11.008

Fernau, E., \& Hirsch, S. (2019). What Drives Dividend Smoothing? A Meta Regression Analysis of the Lintner Model. International Review of Financial Analysis, 61, 255-273. https://doi.org/10.1016/j.irfa.2018.11.011

Graham, J., \& Harvey, C. (2001). The Theory and Practice of Corporate Finance: Evidence from the Field. Journal of Financial Economics, 60, 187-243. https://doi.org/10.1016/S0304-405X(01)00044-7

Grammenos, C. Th., Nomikos, N. K., \& Papapostolou, N. C. (2008). Estimating the Probability of Default for Shipping High Yield Bond Issues. Transportation Research Part E: Logistics and Transportation Review, 44, 1123-1138. https://doi.org/10.1016/j.tre.2007.10.005

Iyer, S. R., Feng, H., \& Rao, R. P. (2017). Payout Flexibility and Capital Expenditure. Review of Quantitative Finance and Accounting, 49, 633-659. https://doi.org/10.1007/s11156-016-0603-Z

Leary, M., \& Michaely, R. (2011). Determinants of Dividend Smoothing: Empirical Evidence. Review of Financial Studies, 24, 3197-3249. https://doi.org/10.1093/rfs/hhr072

Lintner, J. (1956). Distribution of Incomes of Corporations among Dividends, Retained Earnings, and Taxes. American Economic Review, 46, 97-113.

Maniati, M., \& Sambracos, E. (2017). Measuring the Technical Efficiency for the Shipping Banks. Theoretical Economics Letters, 7, 502-516. https://doi.org/10.4236/tel.2017.73038

Rhee, K., \& Park, K. S. (2018). Changes in Dividend Smoothing after the Financial Crisis. Economics Letters, 172, 37-39. https://doi.org/10.1016/j.econlet.2018.08.019 